\title{
FORSYTHE X IKEDA: ONKRAJ FORMULE MULTIPLIKACIJE ILI O ALGORITMU RAZLIKA
}

Pregledni rad

Primljeno: 17. 1. 2018.

Prihvaćeno: 24. 4. 2018.

DOI: $10.15176 /$ vol55no105

UDK 111.852

7.021

\section{LEO RAFOLT}

Odsjek za primijenjenu umjetnost i izvedbene studije Akademija za umjetnost i kulturu, Osijek

Drame veut dire action.

(Rancière 2008: 9)

Krajem 2017. u pariškoj La Villette zatvorena je zajednička izložba instalacija Williama Forsythea i Ryojija Ikede. Njihova zajednička izložba sastoji se od dviju instalacija, predočenih rizomskom matematičkom formulom William Forsythe x Ryoji Ikeda. Riječ je o multiplikaciji, kako unutar vlastitog umjetničkog projekta, svakog od umjetnika osobno, tako i unutar neke transcendentne zajedničkosti instalacijske sheme. Forsythe gledatelja suočuje s prostornom instalacijom, otvorenom koreografijom, naslova Nowhere and Everywhere at the Same Time №2. U njoj su posjetitelji, koji su istodobno autorov koreomaterijal, zarobljeni u mreži nekoliko stotina visaka, obješenih sa stropova galerije. U Ikedinu projektu test pattern [ ${ }^{\circ}$ 13] riječ je o unaprijed zadanoj strukturi crnih i bijelih polja na praznoj podlozi, po kojoj se posjetitelji kreću. Jedino aleatorno kretanje ovdje dolazi od posjetitelja, osobito onih koji pristaju postati koreografiranim objektom, koegzistentnim s instalacijom. Estetika koju autorski dvojac aktivira zasigurno je relacijska, i u smislu moguće koegzistencije i u smislu transpozicije vrijednosti s objekta instalacije na njegovu vlastitu subjektivnost. Instalacijski projekt Forsythe $x$ Ikeda funkcionira kao jedna velika scenografija koja otvara problem simboličkih i praktičkih struktura koje su, u zadanom trenutku, pojedincu omogućile da u tu instalaciju/scenografiju uđe. Demokracija participacije, kohabitacija u jednom zajedništvu (inter)subjektivnosti, razmatra se tako na podlozi suvremenih teorija o relacijskoj estetici i izvedbenoj participativnosti.

Ključne riječi: instalacija, izvedba, participativnost, relacijska estetika 
Svaka je dobra umjetnost svojevrstan laboratorij. Ona je relacijska, odgovara na zahtjeve publike, potom ih uvlači u svoj svijet, poziva ih na neki oblik participacije. Emancipirati gledatelja od vlastite pasivnosti, međutim, iznimno je teška zadaća, koja se pred modernu umjetnost postavila, kao pragma, ističe Claire Bishop (2012), tek negdje s početkom dvadesetog stoljeća, u okrilju povijesnih avangardi ili s konačnom emancipacijom performansa kao live art žanra. Materijalizacijski okvir koji, primjerice, pruža instalacija kao umjetnička forma $u$ velikoj je mjeri rezultat performativno-participatornog i konceptualnog habitusa suvremene umjetnosti kao takve. Teško da bi se nešto što obgrljuje, umrežava ili formatizira prostor - a dobra instalacija zapravo to i čini - vopće moglo tumačiti kao umjetnička praksa bez nekog diskurzivnog okvira. Spas se moderne umjetnosti, ističu mnogi, nalazi u tom diskurzivnom uokvirivanju. Umjetnička se praksa treba braniti, prijete joj istovremeno sile teorije i života. "Umjetničko djelo izlaže se opasnosti da se raspline u bujici diskursa i bujici života te da tako izgubi svoj značaj, svoju predmetnost i sposobnost otpora. Tako odgovor na pitanje o tome što treba obraniti glasi: pojam djela u umjetnosti od razarajućih sila teorije i života" (Groys 2006: 38). Umjetnost je sama po sebi diskurzivna. Instalacijska forma, naime, vlastitu diskurzivnost iznalazi u relacijskom odnosu, služeći se najrazličitijim umjetničkim formama - od videa sve do zvuka. Velike moderne instalacije često izmiču pogledu gledatelja i kompromitiraju njegovo privatno vrijeme, tražeći potpunu posvećenost, dugotrajnu percepciju ili pak neki utjelovljeni angažman. Relativno nedavno, na završetku godine, 31. prosinca 2017, u pariškoj La Villette zatvorena je zajednička izložba instalacija Williama Forsythea i Ryojija Ikede. Njujorški koreograf William Forsythe, koji trenutno živi u Frankfurtu, poznat je po svojim filmskim, izvedbenim i instalacijskim radovima, kako u sklopu The Forsythe Company, koju je ustanovio prije osamnaest godina, tako i u sklopu različitih institucija u kojima je radio kao umjetnički ravnatelj, između ostalog, primjerice, i baleta u Stuttgartu. Ryoji Ikeda, japanski skladatelj elektronske glazbe, istražuje matematičke odnose u glazbi i plastičnim umjetničkim formama, posebice interferencije između zvuka, boje i prostornih odnosa. Njihova zajednička izložba, dakle, sastoji se od dviju instalacija, predočenih rizomskom matematičkom formulom William Forsythe $x$ Ryoji Ikeda. I, uistinu, riječ je o multiplikaciji, kako unutar vlastitog umjetničkog projekta, svakog od umjetnika osobno, tako i unutar neke transcendentne zajedničkosti instalacijske sheme. William Forsythe gledatelja suočuje s (prostoro)instalacijom, svojevrsnom otvorenom koreografijom. Naslovom Nowhere and Everywhere at the Same Time №2 autor je pokušao dočarati algoritamsku prohodnost (prostornost) vlastite instalacije. U njoj su posjetitelji, koji su istodobno autorov koreomaterijal, zarobljeni u mreži nekoliko stotina visaka, obješenih sa stropova galerije. Viskovi se pomiču prema unaprijed zadanom algoritmu, i to u serijama od pedesetak minuta. Međutim, svaki kontakt posjetitelja unutar te mreže mijenja strukturu algoritma te, u prvi mah, prividnu serijsku strukturaciju izlaže minimalnom kaosu. Cijelu strukturu pritom prati posvema serijalna glazba, na prvi pogled kakofonična, ali također ukalupljena u unaprijed zadanu formulu, upravo kao i kretanje visaka. Ikedina instalacija ima 
gotovo istu formu. Čini se da obojica autora dijele isti interes prema serijama, numeričkim sistemima u umjetnosti i matematičkom modelu oblikovanja prostornosti. ${ }^{1}$

II.

U Ikedinu projektu, koji nosi naziv test pattern [nำ13], riječ je o unaprijed zadanoj strukturi crnih i bijelih polja na praznoj podlozi, po kojoj se posjetitelji kreću. Uz agresivnu i kakofonijsku elektronsku glazbu, ta se polja serijalno mijenjaju, po unaprijed zadanom algoritmu, stvarajući strukturu barkodova, generiranu samim protjecanjem vremena. I jedna i druga instalacija, makrostrukturno gledajući, predstavlja neki tip koreografiranog objekta, koliko god to paradoksalno zvučalo. Prvo podrazumijeva dinamiku, egzistenciju sui generis u određenom tipu prostornosti, kao i interakciju s prostornošću kao takvom. Instalacijska bi narav serijskog modela Forsythe $x$ Ikeda, naprotiv, dinamizam takvog tipa trebala dokinuti. Međutim, ta se instalacija pretvara u koreografsko tijelo samo po sebi. Uključuje gledatelja u svojevrsnu zvučnu masu, unutar koje je prisiljen kretati se. U prvom slučaju to je zbog par stotina visaka koji se ne prestaju njihati, pritom stalno mijenjajući ritmičke strukture (tobože) algoritamski precizno usklađene cjeline, u drugom, pak, zbog hipnotičke korespondencije (agresivnog) pozadinskog zvuka i stroboskopske podloge, po kojoj se posjetitelji slobodno kreću. I jedna i druga instalacija zapravo su koreografije $s$ figom u džepu. Labirint zvukova, boja i odnosa u nekoj zajedničkoj prostornosti, dakako, nalaže i specifičan oblik kretanja, model snalaženja u strukturi plastičnih (Forsythe) ili virtualnih (Ikeda) prepreka, u kojoj se dijelovi gledateljeva tijela raskrinkavaju nelinearno, kroz minus-postupak u pokretu, izmicanje nesimetričnoj strukturi njihala, ili pak kroz minus-postupak unutar strukture svjetlosnih intonacija. Posjetitelj, nekoć gledatelj, tako je

\footnotetext{
${ }^{1}$ William Forsythe rođen je u New Yorku. Osnovno je plesačko i koreografsko obrazovanje stekao na Floridi, radeći s Nolanom Dingmanom i Christom Long. Plesao je i u baletnom ansamblu Joffrey i, kasnije, u Stuttgartu, gdje je već 1976. postao stalnim koreografom. Radio je koreografije za baletni ansambl u Stuttgartu, kao i za različite plesno-izvedbene grupe u Baselu, Haagu, Londonu, Berlinu, Frankfurtu, San Franciscu itd. Najpoznatija su mu djela Artifact (1984), Impressing the Czar (1988), Limb's Theorem (1990), The Loss of Small Detail (1991), A L I E / N A(C)TION (1992), Eidos: Telos (1995), Endless House (1999), Kammer/Kammer (2000) i Decreation (2003). Nakon zatvaranja frankfurtskog baleta, u kojem je od 1984. radio, osniva The Forsythe Company, koju će voditi do 2015, stvarajući i neka od svojih najpoznatijih djela, specifične poetike: Three Atmospheric Studies (2005), You made me a monster (2005), Human Writes (2005), Heterotopia (2006), The Defenders (2007), Yes we can't (2008-2010), I don't believe in outer space (2008), The Returns (2009) i Sider (2011). Uz koreografije, radio je na transdisciplinarnim projektima (koreo)instalacija, primjerice s arhitektom Danielom Libeskindom (Groningen, 1989), grupama ARTANGEL (London, 1997), Creative Time (New York, 2005) i SKD - Staatliche Kunstsammlungen Dresden (2013, 2014). Takve je pak instalacije Forsythe nazivao koreografskim objektima, među kojima se ističu sljedeći projekti: White Bouncy Castle (1997), City of Abstracts (2000), The Fact of Matter (2009), Nowhere and Everywhere at the Same Time № 2 (2013) i Black Flags (2014). Njegove su instalacije postavljane u gotovo svim najpoznatijim svjetskim muzejima.
} 
na suptilan način uvučen u (matrično) preciznu koreografiranu izvedbu, koja se sastoji od posve specifičnog razmještaja tijela u prostoru. ${ }^{2}$

III.

Instalacijski nomos, neka unaprijed zadana zakonitost, utvrđen odnos između publike i autora, gotovo da je sastavni dio svakog od tih dvaju umjetničkih projekata odnosno njihova zajedničkog postava. U prvom su, tako, posjetitelji zamoljeni da nipošto ne dodiruju viskove zbog fragilnosti instalacije (što je pri nekim oblicima njihove ritmičke organizacije, naravno, moguće, dok je pri nekim bržim, dinamičnijim serijama njihova kretanja, teško izvedivo), dok su u drugom zamoljeni da po stroboskopski intoniranoj podlozi ne hodaju u cipelama. I u jednom i u drugom slučaju pozvani smo da sudjelujemo u koreografiji, da pratimo prostornu organizaciju instalacije - i njezinu serijalnu egzistenciju. Klasična hermeneutika jasno razlikuje subjekt i objekt izvedbe. Forsythe i lkeda to žele dokinuti, stvarajući svojevrstan estetski tunel za moguću ili pak ponuđenu komunikaciju. Tijelo gledatelja, posjetitelja - barem onih koji pristaju na izvedbu - tako postaje krajnje semiotizirano. Izbjegavajući viskove neki će posjetitelji panično trčati kroz instalaciju, neki drugi će pak smireno osvajati instalacijska polja i sporo napredovati, treći će se pak spontano kretati, čak i plesati, uklapajući se neopterećeno u serijalnu strukturu. Prostor će, na taj način, a osobito u potonjem slučaju, postati inicijator jedne nove semioze, koju serijalnost (matričnost) instalacijskog modela nije ni u kojem slučaju mogla predvidjeti. Slični koreografski moment prisutan je i u Ikedinoj instalaciji. Hipnotička glazbena matrica, također algoritamska - jer se smjenjuje svakih desetak minuta - uvlači promatrače u izvedbeno tkivo, namećući im svojevrsnu koreografiju. Neki će posjetitelji tako plesati, drugi se bojažljivo kretati u oprostorenoj zvukovnosti instalacije, posve nesigurni zbog iznenadnih stroboskopskih promjena ispod vlastitih stopala. Magritovska irupcija teksta u sliku ovdje je prikazana prodorom tijela u instalaciju ili, drugim riječima, utjelovljenjem instalacije kroz unaprijed zadan algoritam. Lako je, naime, zamisliti da se pendularne strukture iz Forsytheove instalacije prestanu kretati, točnije, da se Ikedina kombinatorika zvukova i boja odjednom zaustavi. Dinamičko postaje statično. Živost strukture postaje plastika. Suočeni smo samo s čistošću svjetlosnih efekata, prostora i zvukovnih formi. ${ }^{3}$

\footnotetext{
${ }^{2}$ Ryoji Ikeda je japanski umjetnik zvuka, rođen u Gifuu, koji trenutno živi u Parizu. U svojoj umjetničkoj praksi bavi se zvukom u njegovu najsirovijem obliku, na rubu mogućnosti percepcije. Surađivao je s mnogim grupama, između ostalog s Carsten Nicolai, pod pseudonimom Cyclo, i umjetničkim kolektivom Dumb Type. Zanima ga serijalnost u zvučnim kompozicijama i utjecaj matematičkog rasporeda zvuka na ljudsku percepciju, prostor i vrijeme. Objavio je velik broj albuma i kompilacija te izlagao u najpoznatijim svjetskom muzejima i galerijama.

${ }^{3}$ Minimalizam forme, sveden na svjetlosne efekte i/ili zvuk, nije rijetkost $\mathrm{u}$ instalacijskoj umjetnosti, a nalazimo ga i u suvremenim pristupima kazališnom oblikovanju i u glazbi (Bishop 2005: 56-58).
} 
IV.

Valja se, međutim, zapitati o odnosu dinamičkog i statičkog unutar svake instalacije. Generička pozadina Forsytheova i Ikedina projekta u suštini je koreodramska. Ja oblikujem matematičku formulu, algoritam, pritom stvaram prostorne prepreke, bilo plastične, materijalne, bilo zvukovne, ili pak svjetlosne. Ti si pak prisiljen kretati se. Instalacijski ugovor je narušen - ali ne zbog toga što se tobožnja statičnost muzejskog promatrača dinamizira, nego, ponajprije, jer on postaje subjektom instalacije, a pritom nema izbora. Ne dirajte predmete jer su lomljivi (Forsythe) i izujte cipele (Ikeda). Ostavite svu objektivnost, vi koji ulazite, na pragu unaprijed zadanog algoritma. I u jednom i u drugom projektu nameće se vrlo stroga pravilnost odnosa između matematike linija i točaka. Primjerice, u instalaciji Williama Forsythea svaki pojedini visak pokreće se mehanički, dakle predvidljivo, tako što je poluga postavljena na stropu galerije programirana da ide lijevo, desno, naprijed ili nazad. Umjetnost je uobličena u formuli. Međutim, u baš svakoj mogućoj seriji neki viskovi odustaju od takve pred-strukturacije, odlučujući se na gotovo vlastiti život, izvan forme, izvan matrice, izvan instalacije. Na promjenu $u$ algoritmu ne utječe samo kontakt s koreografiranim i/ili dinamiziranim predmetom, posjetiteljem-izvođačem, nego i otpor samog viska (dakle i instalacije same) da se linearizira, da putuje uvijek istom putanjom. Slično je i s Ikedinom instalacijom. U trenutku kad je, čini se, moguće pronaći liniju segmentacije, ili pak više njih, na velikom bijelom polju (pre)opterećenom svjetlećom koreografijom, polje se iznenada mijenja. Zvuk vodi i koreografira svjetlost. Ili obrnuto. Visak nije nužno dodirnuti kako bi se sudjelovalo u globalnoj koreostrukturi Forsytheove instalacije. U Ikedinoj instalaciji, također, nije potrebno tražiti demarkacijske linije (koje se pojavljuju kao rezultat serije, forme, upisane formule ili algoritma), da bi se sudjelovalo. Prijelomi u strukturi nastaju upravo ondje gdje dolazi do multiplikacije forme, gdje egzistira $x$. Svaku od navedenih instalacija moguće je pogledati i s uzvišene platforme, koja posjetiteljima otvara svojevrsni globalni pogled, multiplicira njihovu interpretaciju (ono što vidim, ti ljudi koji se tamo kreću, to sam bio i ja), uvjeravajući ih da tako prestaju biti dijelom matrice. Formula se raskrinkava onkraj forme, nipošto u formi samoj. Il n'y a pas de hors formule. Unutar matrice nije moguće sagledati cjelinu razdjelovljenja instalacije, koja se oku gledatelja - tek s globalnog motrišta, malo poviše - raskrinkava kao neka vrsta izvedbeno-umjetničkog menadžmenta, koji ne multiplicira tek svoje sastavne dijelove, njihala, boje, tonove, zvukove, nego i svaki potencijalni participativni element. $U$ tome se i nalazi suština formule Forsythe $x$ Ikeda, koja je ušla i u naslov zajedničkog projekta.

V.

Louis Althusser $u$ jednom od svojih posljednjih eseja piše o svojevrsnom aleatornom materijalizmu ili pak materijalizmu susreta, kojem je polazište kontingencija svijeta, bez porijekla, bez izvorišta, bez unaprijed zadanog smisla i uzroka koji bi mu odredio cilj. Bez 
jasne teleologije. Forma postaje trajni susret, relacija. Naše vizualno iskustvo postaje složenije, obogaćeno filmskom sekvencionalnošću, zbog koje jedan svijet percipiramo kao skup razbacanih elemenata, koje ne povezuje nikakva sjedinjujuća materija, plastika ili bronca, odnosno nikakvo strukturalno ljepilo (Bourriaud 2013: 24-26). Taj zbroj jedinica materijalizira se tek pogledom, točnije - oživljava se upravo sudioništvom. Ljepilo instalacijske formule, formalno vezivo Forsythe $x$ Ikeda nalazi se upravo u multiplikaciji. A filozofija multiplikacije je uistinu specifična. I dok se zbrajanjem i oduzimanjem manipulira sličnostima kako bi se dobio zbroj ili razlika sličnosti, množenje se, kao matematička funkcija, raskrinkava u multiplikaciji različitosti zbog (dobivanja) različitosti same. To je itekako vidljivo u ovom zajedničkom instalacijskom projektu, koji je svoju premijeru imao na Trijenalu u Ruhru, gdje je opisan upravo kao struktura napetosti, suprotnosti, dakle različitosti. Svijet je Forsytheove instalacije pitom, miran, staložen, s minimalnim strukturama pokreta. Zapravo, jedino aleatorno kretanje ovdje dolazi od posjetitelja, osobito onih koji pristaju postati koreografiranim objektom, koegzistentnim s instalacijom. S druge strane, svijet Ikedine instalacije je agresivan, nametljiv, prodoran, pri čemu ga baš sudionici primiruju, opet pristajući ući u takav koreolabirint. Komplementarnost ovih dvaju svjetova, ove dvije instalacije, vidljiva je, stoga, barem na tri razine. Prva bi uključivala tjelesnost sudionika, koji se i u prvom i u drugom slučaju kreću. Oni su osuđeni na kretanje, izmicanje, aktiviranje različitih dijelova tijela u nelinearnom slijedu. Okruženi viskovima, to im je izmicanje neminovno. Izloženi agresivnim svjetlima i pod snažnom nelinearnom stroboskopskom intonacijom, čak i da se ne kreću, oni se naizgled (po)kreću. Druga se razina odnosi na vrijeme, točnu predodređenost svake serije, unutar koje opet ništa nikad nije isto. Treća, konačno, obuhvaća prostornost same instalacije. I Forsytheova i Ikedina struktura, pak, imaju jasan okvir koji se, međutim, multiplicira ne samo unutar svake serije nego i svakom serijom. Primjerice, Forsytheova njihala nikad se u potpunosti ne mogu zaustaviti, dakle ne postoji prazan hod između serija, kao što se i lkedine svjetlosne strukture ne prekidaju, i nemoguće im je ući u algoritamsku svijest. Naime, multiplikacija ih dinamizira u različitosti, a opet u nekom čudesnom reciprocitetu. Njihov je organizacijski habitus uvjetovan tehnološkom izvedbom, nekim pozadinskim mehanizmom koji ih pokreće, ali i takav je mehanizam ponovno determiniran nizom nadređenih mu metastruktura, koje se umnažaju - ili množe - upravo zbog inicijalnog poziva na participaciju.

VI.

Umjetničko djelo nastoji zarobiti pogled, poput djeteta iznalazi vlastitu ekspoziciju. Instalacijski projekti Forsythea i Ikede nastoje, s druge strane, zarobiti pokret, odnosno iznaći vlastitu performativnost. Njima je zapravo izvedba prirodan komunikacijski kontekst. Forsythe je i u drugim svojim projektima istraživao tu mekoputnost odnosa između subjekta i objekta u koreografskom diskursu. Primjerice, njegove video-projekcije o improvizacijskim 
tehnologijama iz 1995. rezultirale su izvedbom Self Meant to Govern, prvim dijelom cjelovečernjeg performansa Eidos: Telos (1995), u kojem plesači s monitora dobivaju informacije o mogućim pokretnim strukturama. Ikedina koreostruktura, za razliku od one imputirane, nužno aktivne, aktivirajuće, Forsytheove, s druge pak strane, dinamizira tijelo igrom svjetlosno skrivenog i raskrinkanog, pri čemu dinamizam sudionika nije od tako velike važnosti. lako se $u$ obje instalacije pogled nameće kao jedan od središnjih elemenata (izvedbe) instalacije, tranzitivnost se cjelokupnog procesa može u svakom trenutku dovesti u pitanje. Konačni algoritam i konačna formula tako ostaju vješto skriveni. Ono što se u svakom trenutku kreće kod Forsythea (visci, njihala, pendularne strukture), naravno - uz glazbu, u lkede je također dinamičko, u strukturi plošnih linija, nalik barkodovima, koje se velikom brzinom, nelinearno, smjenjuju na bijeloj površini. Ono što je kod Forsythea vertikalno, $u$ Ikede je smješteno na horizontalnoj ravni. U Williama Forsythea su sudionici uvučeni u instalaciju, isključivo, odozdo prema gore, kao u neku delezovsku rizomsku jednadžbu. Kod Ikede je instalacija njima subordinirana, štoviše - po njoj se i kreću. Međutim, plastičnost se tijela sudionika i u jednog i u drugog autora postiže istim mehanizmom, gotovo istom strategijom - transpozicijom središnjeg algoritma na tijelo $u$ prostoru ili formulom tijelo $x$ prostor $x$ vrijeme. Svjetlosni efekti kod Ikede tijela će sudionika činiti plastično-skulpturalnim na isti način kao i kod Forsythea, u čijem će instalacijskom univerzumu svjetlost (koja je prostor $x$ vrijeme, otkrivanje i skrivanje prostora u vremenu) zamijeniti jedva vidljiva nit koja povezuje visak, njihalo, sa stropom galerije.

VII.

Estetika koju autorski dvojac aktivira zasigurno je relacijska, i u smislu moguće koegzistencije i u smislu, o kojem sam govorio ranije, transpozicije vrijednosti s objekta instalacije na njegovu vlastitu subjektivnost. Moraš se kretati. Imperativ dinamike je imperativ strukture instalacije. Forma se instalacije tog tipa tako i zasniva na precizno definiranoj formuli dinamizacije. Ako glazba nije dovoljna, na kretanje će potaknuti prepreka u samoj prostornosti, njihalo, visak, njegova nit koja segmentira prostornost, odnosno, u lkede, igra skrivenog i razotkrivenog svjetlosnom instalacijom. Riječ je, dakle, o svojevrsnom pozivu na izlazak iz pasivne pozicije, uz stalno upozorenje - molimo vas, ne dodirujte njihala, budite oprezni, agresivan zvuk, stroboskopsko osvjetljenje. Poziv na participaciju uvelike produbljuje jaz između tobože aktivne izvedbe i pasivne publike. Ovdje je on, ipak, formuliran via negationem, gotovo kao otvoren poziv na sudioništvo i aktivaciju svojevrsne koreografske intuicije. Nije li težnja kojom se želi eliminirati jaz između pasivnosti i aktivnosti u izvedbenom procesu, paradoksalno, ona koja taj jaz, tu pukotinu, ustvari i produbljuje. Ovaj instalacijski projekt opoziciju između gledanja (viđenja) i djelovanja u potpunosti dovodi u pitanje, na taj je način ostavljajući zarobljenu u binarizmu dominacije i podređenosti (subjekcije). Jacques Rancière je razvio ideju emancipiranog gledatelja na temelju koncepcije žive zajednice u 
brehtovskom ili artoovskom kazalištu i izvedbenim umjetnostima koje nastaju na tom modelu. Autor kritizira Debordov model glupog i pasivnog promatrača, iskalupljujući ga kako iz dihotomije koja ga konceptualizira, pasivno i/ili nemoćno nasuprot aktivnom i/ili moćnom, tako i iz obrazovne stereotipije tobožnje nemogućnosti i ignorancije ili intelektualne podređenosti potonjem. Dakle, želja kojom se nastoji dokinuti neprirodna distanca između gledatelja i umjetničkog djela, koja je s vremenom postala rigorozna, prema Rancièreu, instrumentalizira se jedino u ponovnom stvaranju i produbljivanju te distance. "Emancipacija počinje kad opoziciju između viđenja i djelovanja dovedemo u pitanje; kad shvatimo kako samorazumljive činjenice koje strukturiraju odnose između govorenja, viđenja i djelovanja, same po sebi, pripadaju strukturi dominacije i subjekcije" (Rancière 2008: 19). Forsytheova i Ikedina instalacija uistinu se stvara kao kreativna (su)igra asocijacija i disocijacija, unutar koje estetski učinak nije zagarantiran ili, ransijerovski rečeno, egzistira tek u prostoru u kojem svaki pojedini gledatelj stvara vlastiti estetski sud, koji je, naime, i u potencijalnom disenzusu sa svim drugim sudovima. Kritizirajući istodobno marksističku paradigmu i Bourdieua, stvarajući jaz između klasne uvjetovanosti i estetske mogućnosti, autor ističe: “Kolektivno razumijevanje emancipacije nije pak shvaćanje totalnog procesa subjekcije. To je kolektivizacija kapaciteta koji su bili investirani u uprizorenje disenzusa" (Rancière 2008: 55). Instalacijska matrica Forsythe $x$ Ikeda individualizira estetsko iskustvo te ga, istodobno, poopćuje, čineći ga globalnim, univerzalnim. Paradoks komunalne političnosti i, nadalje, individualne estetičnosti ovih instalacija nalazi se u ransijerovskom konceptu socijalne emancipacije kroz estetsku proceduru. Separes, on est ensemble. Osjetilnost umjetničke proizvodnje - $u$ Forsytheovu ili pak Ikedinu slučaju riječ je o hipersenzibilnim instalacijskim matricama - i osjetilnost konzumacijskog užitka, naravno, nije moguće propisati, jer ne postoji neka direktna putanja od čina gledanja nekog umjetničkog procesa do razumijevanja svijeta, od intelektualne podraženosti umjetnošću do političke akcije itd.

VIII.

Rancière sugerira da umjetnost, slika, nikad ne egzistira sama po sebi. Ona već unaprijed pripada sustavu vidljivog koji upravlja reprezentacijom, štoviše - i pozornošću. Svrha je umjetnosti, stoga, stvarati mnoge paralelne stvarnosti, različite modalitete zdravorazumskog i/ili pojmljivog, različite prostorno-vremenske sustave, zajednice riječi i stvar, oblika i značenja (isto: 112). lako se čini da instalacija o kojoj je ovdje bilo riječi robuje nekom vrhunaravnom, transcendentalnom (matematičkom) algoritmu - kojeg su učinci posve predvidljivi - njezina je estetika, sasvim suprotno, u potpunosti kontingentna. Ona sadržava misao koja ne može nipošto biti atribuirana nekoj višoj umjetničkoj intenciji, kao da egzistira u nekoj zoni neodlučnosti, između umjetnosti i ne-umjetnosti, između misli i ne-misli, između aktivnosti i pasivnosti, između instalacije i koreografije. Sama je po sebi misleća (pensive). U njoj se krije neki agonalni zametak, neki antagonizam između insta- 
lacijskog sada, umjetničke trenutnosti, i (koreo)izvedbenog in spe. "Čak i kad dramaturg ili izvođač ne zna što želi od gledatelja da učini, zna barem toliko da gledatelj mora nešto učiniti [...] Što manje dramaturg zna to što gledatelji moraju napraviti kao kolektiv, to više zna da oni baš moraju postati kolektiv, pretvoriti svoju prostu aglomeraciju u zajedništvo koje virtualno jesu" (isto: 21-22). Dvije se instalacije u pariškoj La Villette multipliciraju i u svojoj participativnosti i u svojoj komunitarnosti. Umjetnički je prostor instalacije pretvoren u javni prostor $u$ kojem egzistira sama frikcija između, s jedne strane, onog što gura umjetnost prema životu i, s druge, onog što jasno odvaja estetsku osjetilnost od drugih oblika osjetilnog iskustva. ${ }^{4}$ Relacijska narav takvog instalacijskog pothvata, dakako, vidljiva je i u reakcijama gledatelja koji, čini se, svi odreda, pristaju biti sudionicima izvedbenog procesa, a neki se čak uklapaju u performativnost instalacije, primjerice plešući i/ili stvarajući vlastiti korpografski iskaz. Participativnost ne multiplicira samo doživljaj, estetsko iskustvo, nego i sastavne elemente samog umjetničkog projekta. Ulazak u matricu, u unaprijed programirani test pattern, u obje instalacije, štoviše, podrazumijeva ulazak u zonu nesigurnosti, odnosno potpuno podređivanje umjetničkom diskursu, dakle subjekciju onkraj bilo kojeg unaprijed zacrtanog emancipatorno-ideološkog projekta. To je i pristanak na stvaranje privremene zajednice. Zajednica nije ništa drugo nego inklinacija među pojedincima. Ona je, u biti, “klinamen 'individue'. Ali nijedna teorija, nijedna etika, nijedna politika, nijedna metafizika individue nije sposobna sagledati taj klinamen, to sklanjanje ili zapadanje individue u zajednicu [...] Individualizam je nedosljedan atomizam koji zaboravlja da je ulog atoma svijet" (Nancy 2004: 10). Zajednica koju stvara Forsytheov i lkedin instalacijski univerzum transcendira svaki mogući oblik singularnosti, nalaže dioništvo ti-u-ja, sugerira djelo koje već podrazumijeva zajednicu - pritom je stoga nipošto ne stvara. "Zajednica se nužno zbiva u onom što je Blanchot nazvao razdjelovljenje [u knjizi L'espace littéraire, 1955] - s ove ili s one strane djela, ono što se povlači od djela, ono što nema više posla ni s proizvodnjom ni s dovršenjem, nego ono što doživljava prekid, razlomljenost, obustavu. Zajednicu tvori prekid singularnostî, odnosno obustava koja singularna bića jesu. Ona nije njihovo djelo niti ona njima raspolaže kao svojim djelima - podjednako kao što ni komunikacija nije djelo, pa čak ni djelovanje singularnih bića: jer ona je naprosto njihovo bivanje - njihovo bivanje obustavljenim na granici. Komunikacija je razdjelovljenje društvenog, ekonomskog, tehničkog, institucionalnog djela" (isto: 39). Generički habitus instalacije uvelike se naslanja na umjetnost prostora i potencijalnu sposobnost posjetitelja da se u nekom prostoru pronađu. Instalacijske su forme povezane s gledateljevim iskustvom po liniji participacije već i samom činjenicom da su uglavnom toliko velike da ih posjetitelji moraju sagledati iznutra, neutralizirajući vlastitu distancu. Forma se instalacije, štoviše, stvara u nekoj zajedničkoj inklinaciji umjetnika i gledatelja-sudionika prema istom ili sasvim različitom doživljaju, slično kao i u mnogim drugim ambijentalnim umjetničkim formama, primjerice u happeningu (Bishop 2005: 6-47). Veći i percepcija sama, u slučaju instalacijske umjetnosti, gledatelja uvlači u neki oblik izvedbe, decentrirajući njegovu pozornost, poput performansa ili za-

${ }^{4}$ Zanimljivu interpretaciju i primjenu Rancièreovih teza daje Claire Bishop u uvodnom poglavlju svoje knjige (2012: 11-40). 
mišljene konceptualne kazališne izvedbe. Ako se prihvati teza o nekoliko paradigmatskih lica izvedbenog procesa, od kojih se na instalacijski habitus projekta Forsythe $x$ Ikeda može primijeniti nešto između umjetničke i tehnološke izvedbe, moguće je zaključiti da je poetika dvojice autora usmjerena prema stvaranju idealne algoritamske strukture u kojoj će pendularni obrazac, formula viska, s jedne, odnosno svjetlosni barkod s druge strane, na bijeloj podlozi, objasniti kontingentnost svake moguće umjetničke participacije.

\section{IX.}

Barkod, čini se, uistinu i jest diskurzivni obrazac tehnološke izvedbe. "Tko čita barkodove? Zapravo, nitko - ljudske jedinke koje ga mogu izravno pročitati veoma su malobrojne, ako ih uopće ima; no očitava ga silno mnoštvo strojeva, točnije tehnologija laserskog skeniranja" (McKenzie 2006: 31). Svaka instalacija, s tim da je definiramo kao osobitu strukturu, kao izvedbu koja posjeduje elemente umjetničke, tehnološke i organizacijske naravi, jasno se odnosi prema vlastitoj društvenoj čimbenosti (efficacy), prema izazovima svoje učinkovitosti (efficiency) i djelotvornosti (effectivness) (isto: 46-50). Instalacija koja me na ovom mjestu zanimala svojevrstan je stroj za samouprizorenje, autoperformativni mehanizam koji će, izvana, rijetko kad odavati algoritam vlastite strukturacije, neki inherentni (tehno) organizacijski princip, dok će, naprotiv, tek posvemašnjom emancipacijom posjetitelja, njihovim prepuštanjem zadanoj formuli ili pak jednadžbi instalacije, globalna formula koja stoji iza umjetničkog procesa postajati jasnijom. U tom izvedbenom procesu - između posjetitelja i umjetničke instalacije - dakako, iskrsava mnogo neuslojenih, destratificiranih elemenata, koji će na algoritam instalacije itekako utjecati. Uostalom, posjetitelj (kojem je oduzeto pravo na pasivnu egzistenciju, koji ne može biti naprosto gledatelj, osobito nastoji li prodrijeti u suštinu algoritma izvedbenog procesa) nije u mogućnosti odabrati vlastito mjesto, njegovo je kretanje, stoga, rezultat imperativa izvedbe. Pritom se, posljedično, stvara svojevrsna aporija o postojanju održive pozicije, primjerice poviše, postrani, sučelice ili izvan cijele instalacije, u nekim "džepovima iterabilnosti, autoreferencijalnim rupama u kojima se izvanjsko izvrće na unutra" (isto: 50 ). ${ }^{5}$ Tu aporiju bi, u teorijskom smislu, mogla otkloniti i sama povijest instalacije kao umjetničke forme koja je upravo zbog svoje veličine nalagala participativnost. Nadalje, u čisto pragmatičnom smislu, čini se, vidljivost je uvijek zamka jer izaziva voajerizam, doziva nadzor i provocira nagon za posjedovanjem (Phelan 1993: 6). Ovdje, naprotiv, ulaženje u svijet instalacije podrazumijeva i napuštanje zone vidnosti, razlučivosti, subjektnosti, prava na uvid, odnosno ulazak u područje prave tranzitivnosti.

Koncept tranzitivnosti uvodi u estetičko polje onaj formalni nered svojstven dijalogu. Njime se poriče postojanje posebnog "mjesta umjetnosti" u korist nikada završene

${ }^{5}$ Takvi će se džepovi otpora u izvedbi često nazivati hlapidbom (perfumance) (McKenzie 2006: 48-50, 249-348) 
diskurzivnosti i nikada utažene želje za diseminacijom [...] Jednom riječju, mreža "umjetnost" porozna je, a upravo odnosi te mreže sa svim proizvodnim poljima određuju njezin razvoj [...] No povijest umjetnosti općenito se može čitati kao povijest sukcesivnih polja, izvanjskih relacijskih polja međusobno povezanih praksama koje su određene unutrašnjom evolucijom tih polja. (Bourriaud 2013: 32-35)

Benjaminovska aura umjetnosti kao da je u suvremenim umjetničkim formama prešla na publiku, na uključenog i emancipiranog gledatelja, odnosno na relaciju samu, na njezinu apriornu estetičnost. $\mathrm{Na}$ jednom mjestu Bourriaud ističe kako su pukotine u kojima se smještaju participativni projekti, istodobno, i mjesta gdje se promišljaju alternativni oblici društvenosti, novi kritički modeli zajedništva. Instalacijski je proces, kao i cjelokupna suvremena umjetnost, izmjestio porijeklo i učinak aure umjetnosti, koja postaje projekcija u jednom, $\mathrm{u}$ isti mah, (su)kreativnom i (su)asocijativnom procesu, u relaciji s participirajućom zajednicom posjetitelja (isto: 56-76). U Forsytheovu projektu, tako, svaki pojedinac koji ulazi $u$ instalaciju pristaje sudjelovati u nekom njemu nadređenom participatornom umjetničkom zajedništvu, dok se u Ikedinoj instalaciji bijela, stroboskopski intonirana podloga pretvara u veliki umjetnički ekran, u kojem se, prvo, zrcali dinamika samih posjetitelja i, drugo, puno važnije, na kojem se ne izmjenjuje samo svjetlost crno-bijelih linija nego i informacija (u formi barkoda). Bourriaud napominje kako u toj "relaciji" ekrana iskrsava jedan paradoks, stoga što "istu riječ upotrebljavamo za površinu koja zaustavlja svjetlost (u kinu) i zaslon na kojem se ispisuju informacije" (isto: 80). ${ }^{6}$ Posjetitelji su, u Ikedinu slučaju, ne samo svjetlosno koreografirani, o čemu sam već govorio, nego i in-formirani, upisani u informacijsku ili, McKenziejevim rječnikom, tehnologijsku izvedbu, koja zahtjeva posve nove registre percepcije ili nove modele participacije. Instalacijski projekt Forsythe $x$ Ikeda funkcionira kao jedna velika scenografija, koja mami svojom dinamikom, ali, istodobno, koja otvara problem simboličkih i praktičkih struktura koje su, u zadanom trenutku, pojedincu omogućile da u tu instalaciju/scenografiju uđe. Demokracija participacije, valja istaknuti, nikad nije bez posljedica. Ovdje je, čini se, ponajviše, riječ o prisilnoj kohabitaciji u jednom zajedništvu (inter)subjektivnosti. Svijest o instalacijskoj shemi ne nalaže pojedincu priznavanje tek neke više formule, globalnog algoritma, nego i spoznaju vlastitog položaja u toj formuli, i to kao jednog od više njih, kao jedne mogućnosti. Subjektivnost se, štoviše, time denaturalizira, ona egzistira u kaosu strukture i u kontingenciji. Nitko u ovom projektu ne posjeduje monopol na subjektivnost. Tehno-izvedba, s kojom se poigrava McKenzie, zapravo je stroj za denaturalizaciju subjekta u izvedbi. Uvodno određenje tehno-izvedbe, koje daje autor, zapravo se svodi na fenomen djelotvornosti na točno određenom zadatku, gdje je pravi primjer računalo, kao metamodel tehno-izvedbe. McKenzie se, doduše, ovdje koristi radikalnim primjerom teorijske kohabitacije računarstva i umjetnosti, točnije kazališta, koji daje Brenda Laurel. Ona, naime, funkcije računala doživljava kao čiste kazališne funkcije, pri čemu se tehnologije ne definiraju kao znanstveni instrumentarij, nego kao

${ }^{6}$ U hrvatskom jeziku dihotomija je naglašenija ili snažnija, upravo u svojoj frazeološkoj stratifikaciji, jer se, relativno nedavno, za kinematografski ekran počeo upotrebljavati naziv projekcijsko i filmsko platno, sugerirajući na taj način čisto umjetnički režim filmskog medija (paralela sa slikarskim platnom). 
umjetnički medij. Njezina se strategija zasniva "na teorijskoj obradi interakcije čovjeka i računala ( $\mathrm{HCl}$ [tj. Human-Computer Interaction]) u smislu kazališnoga prikazivanja, a napose estetike koju nalazimo u Aristotelovoj Poetici. Aristotelovih šest elemenata tragedije (vizualni dio predstave, skladanje napjeva, dikciju, karaktere, misli i fabulu) i četiri uzroka (tvar, oblik, uzrok kretanja i svrhu) sustavno prevodi na područje oblikovanja sučelja" (McKenzie 2006: 170-171)?? Instalacijski proces o kojem je ovdje bilo riječi također predstavlja veliko sučelje za eksperiment, i zahtjeva feedback, za koji se, izgleda, ne može reći da je uvijek iniciran samom instalacijom. Nema pravila. Bourriaud se pri analizi modelâ denaturalizacije subjektivnosti u suvremenoj umjetnosti poslužio čitanjem Félixa Guattarija, koji tvrdi da ništa nije manje prirodno od subjektivnosti, koja je potpuno konstruirana, obrađena i izgrađena. Ne ulazeći suviše u Bourriaudovo čitanje Guattarija, treba istaknuti nekoliko obilježja te denaturalizacije, važnih i za zaključno slovo u analizi projekta Forsythe $x$ Ikeda. Prvo, subjektivnost se može odrediti jedino (su)prisutnošću druge subjektivnosti, "ona tvori 'teritorij' samo na temelju drugih teritorija koje susretne; kao evolutivna tvorevina, ona se oblikuje iz razlike koja je stvara, prema načelu drugosti [...], a Guattari definira subjektivnost kao ukupnost odnosa između pojedinca i individualnih ili kolektivnih, ljudskih ili neljudskih nositelja subjektivacije na koje on nailazi. To je odlučujući proboj: bit subjektivnosti tražila se kod subjekta, a pronađena je, zauvijek decentralizirana, uhvaćena u svojim 'semiotičkim neznačenjskim porecima'” (Bourriaud 2013: 110-111). Suvremena umjetnost, posebice instalacijska forma, stoga, potiče rađanje upravo takve decentrirane subjektivnosti, ovisne o integraciji označitelja u neke strane ili njemu izvanjske teritorije. To dovodi do drugog modela Guattarijeva mišljenja, koji je za Bourriauda operativan. I procesi proizvodnje subjektivnosti moraju se redefinirati, moraju biti oplemenjeni kontekstualizacijom, jer monopol nad subjektivnošću ne postoji. Tu Bourriaud Guattarijeve teze dovodi u korelaciju s tezama iz hjustonskog predavanja Marcela Duchampa iz 1954, gdje on govori o kreativnom procesu u kojemu je promatrač redovito suautor umjetničkog djela. Štoviše, u tajne stvaranja on prodire preko "umjetničkog koeficijenta" ili "razlike između onoga što je (umjetnik) zamislio stvoriti i onoga što je stvorio" (Duchamp, prema Bourriaud 2013: 121). U instalaciji Williama Forsythea i Ryojija Ikede umjetnički koeficijent nalazi se upravo u algoritmu koji je i pokreće, kao i u nesigurnosti, labavosti takve algoritamske strukture, koju minimalni fazni pomak može modificirati. Participacijska narav ove instalacije, samim time, oslanja se na destratificirane, nehijerarhijske - ili, štoviše, antihijerarhijske - umjetničke strukture, koje se najčešće u teorijskim raspravama određuju fenomenima aktivacije i uključenosti promatračâ u proces, fenomenom kontingentne autorske pozicije i, naposljetku, ponovne uspostave komunitarnosti percepcije, toga, $u$ isti mah, kohezivnog i razdjelovljujućeg faktora. ${ }^{8}$ Muzej danas više ne može funkcionirati kao arhiv predmeta ili deponij vrijednosti. U njemu se danas deponiraju različite strategije pogleda, koje se

\footnotetext{
7 Nešto slično se uistinu i dogodilo 1995. u njujorškoj Silicon Alley, gdje je osnovana medijska tvrtka SiteSpecific, čiji su se osnivači, oslanjajući se na iskustva u izvedbenim umjetnostima, bavili in situ internetskim izvedbama. Sličan je primjer i MacroMedijin softver Director, koji služi za stvaranje interaktivnih platformi (McKenzie 2006: 172).

${ }^{8}$ Svaki bi se od navedenih fenomena, naravno, mogao i detaljnije razraditi (Bishop 2006: 10-17).
} 
mogu - u svakom trenutku - iz tog arhiva izvaditi i redistribuirati, ponovno primijeniti. Instalacijski projekt Forsythe $x$ Ikeda trebalo bi sagledati upravo u tom kontekstu redistribucije strategija gledanja i, posljedično, sudjelovanja, na toj mekoputnoj granici estetskog režima kohabitacije i etičkog režima suodgovornosti i sustvaralaštva.

\section{NAVEDENA LITERATURA I IZVORI}

Bishop, Claire. 2005. Installation Art. A Critical History. London: Tate.

Bishop, Claire. 2006. "Introduction. Viewers as Producers". U Participation. Douments of Contemporary Art. London, Cambridge/MA: Whitechapel Ventures Ltd., The MIT Press.

Bishop, Claire. 2012. Artificial Hells. Participatory Art and the Politics of Spectatorship. London: Verso.

Bourriaud, Nicolas. 2013. Relacijska estetika / Postprodukcija. Kultura kao scenarij. Kako umjetnost reprogramira suvremeni svijet. Zagreb: Muzej suvremene umjetnosti.

Groys, Boris. 2006. Učiniti stvari vidljivima. Strategije suvremene umjetnosti. Zagreb: Muzej suvremene umjetnosti.

McKenzie, Jon. 2006. Izvedi ili snosi posljedice. Od discipline do izvedbe. Zagreb: CDU - Centar za dramsku umjetnost.

Nancy, Jean-Luc. 2004. Dva ogleda - Razdjelovljena zajednica / O singularnom pluralnom bitku. Zagreb: Multimedijalni institut, Arkzin.

Phelan, Peggy. 1993. Unmarked. The Politics of Performance. London, New York: Routledge. [https://doi. org/10.4324/9780203359433]

Rancière, Jacques. 2008. Le spectateur émancipé. Paris: La Fabrique éditions.

\section{FORSYTHE X IKEDA: BEYOND FORMULA MULTIPLICATION OR ON THE ALGORITHM OF DIFFERENCE}

This paper deals with two installation projects created by William Forsythe and Ryoji Ikeda for a mutual exhibition, thus focusing on the participatory and performative context of these artistic projects. Both installations are deeply performative, as they ask the audience to create their own choreographic mode of participation. This participation demand is, furthermore, examined both in the context of installation art history and in the context of Rancière's writings on the problems of emancipation in artistic regimes. Finally, this paper offers a specific view on the problems of techno-performance, as well as on the concepts of participation and perception in such mega-installation processes.

Keywords: installation, emancipation, participation, techno-performance, aesthetic regime 